\title{
Genetic, dietary, and other lifestyle determinants of serum homocysteine levels in young adults in Costa Rica
}

\author{
Ileana Holst-Schumacher, ${ }^{1}$ Rafael Monge-Rojas, ${ }^{2}$ \\ Priscilla Cambronero-Gutiérrez, ${ }^{1}$ and Gilbert Brenes ${ }^{3}$
}

Suggested citation Holst-Schumacher I, Monge-Rojas R, Cambronero-Gutiérrez P, Brenes G. Genetic, dietary, and other lifestyle determinants of serum homocysteine levels in young adults in Costa Rica. Rev Panam Salud Publica. 2005;17(4):263-70.

ABSTRACT Objective. Elevated serum total homocysteine ( $t$ Hcy) is considered an independent risk factor for cardiovascular disease. The objective of this study was to develop the first-ever information on the prevalence of hyperhomocysteinemia and its determinants in a population in Costa Rica.

Methods. A cross-sectional study was conducted to determine serum levels of tHcy, vitamin $B_{12}$, folate, and creatinine, as well as the presence of the genotype TT for the methylenetetrahydrofolate reductase (MTHFR) enzyme. Additionally, dietary vitamin intakes and other lifestyle risk factors were assessed. A total of 399 Costa Rican adults from the central valley of the country (where the capital city, San José, is located), aged 20 to 40 years, participated in this study in the year 2000. Analyses of variance were performed for continuous variables, and the chi-square test was used for categorical data. Spearman correlation tests were calculated to determine associations between variables. Three linear regression analyses and one binary logistic model were developed in order to determine the predictors for homocysteine levels in the population studied.

Results. The overall prevalence of hyperhomocysteinemia (> $15 \mu \mathrm{mol} / \mathrm{L}$ ) in the population was $6 \%, 31 \%$ of the population were in the range of 10 to $15 \mu \mathrm{mol} / \mathrm{L}, 29 \%$ had the genotype TT for the enzyme MTHFR, $18 \%$ presented a vitamin $B_{12}$ deficiency $(<165 \mathrm{pmol} / \mathrm{L})$, and none of the persons had low serum folate levels $(<7.0 \mathrm{nmol} / \mathrm{L})$. No significant associations were found between tHcy and age, smoking, consuming alcohol, or dietary vitamin intake.

Conclusions. Only serum vitamin $B_{12}$ levels and the genotype TT of the enzyme MTHFR were considered significant predictors of high serum tHcy levels in the Costa Rica population studied.

Key words Cardiovascular diseases, homocysteine, life style, risk factors, Costa Rica.

1 University of Costa Rica, Investigation Center for Abnormal Hemoglobins and Related Sicknesses, San Pedro de Montes de Oca, San José, Costa Rica. Send correspondence and requests for reprints to: Ileana Holst-Schumacher, Investigation Center for Abnormal Hemoglobins and Related Sicknesses
(CIHATA), University of Costa Rica, Postal Code 2060, San Pedro de Montes de Oca, San José, Costa Rica; fax: (506) 225-2374/(506) 207-5440; telephone: (506) 207-5440/(506)207-4389; e-mail: iholst@ cariari.ucr.ac.cr
2 Costa Rican Institute for Research and Education on Nutrition and Health, Tres Ríos, Cartago, Costa Rica.

3 University of Costa Rica, Central American Population Center and School of Statistics, San Pedro de Montes de Oca, San José, Costa Rica. 
Since 1970, researchers have linked hyperhomocysteinemia to cardiovascular disease (CVD), and hyperhomocysteinemia is now considered a CVD risk factor (1). Low serum concentrations of folate, vitamin $\mathrm{B}_{12}$, vitamin $\mathrm{B}_{6}$, and vitamin $B_{2}$ have been identified as risk factors for hyperhomocysteinemia (2). Folate is considered the micronutrient with the greatest impact on homocysteine metabolism (2).

Several genetic defects in the enzymes participating in the homocysteine metabolic cycle have also been associated with hyperhomocysteinemia (3). Frosst et al. (4) identified a common point mutation (C677T) in the methylenetetrahydrofolate reductase (MTHFR) gene that correlated with reduced MTHFR activity. Homozygotes for this enzyme variant have significantly elevated total homocysteine (tHcy) levels, suggesting that this mutant gene may be a risk factor for developing hyperhomocysteinemia $(3,4)$.

Moderate hyperhomocysteinemia is equivalent to hypercholesterolemia as a cardiovascular risk factor. Given that, some researchers have pointed to the importance of knowing and reducing the tHcy concentrations in a population in order to lower CVD mortality (5). This is important in Costa Rica, where CVDs constitute the leading cause of death among adults, with a mortality rate of 80.4/10 000 in 2001, and where approximately $2.5 \%$ of those deaths occurred among relatively young persons, that is, under 40 years of age (6).

Some researchers have studied the traditional CVD risk factors among adults in Costa Rica (7), but there are no data available on the prevalence of hyperhomocysteinemia and its determinants in the country. This is the first study that describes the distribution of tHcy and its determinants among Costa Rican adults.

\section{MATERIALS AND METHODS}

\section{Subject selection}

A sample of 399 Costa Rican volunteers aged 20 to 40 years participated in this study, which was conducted in the year 2000. Subjects were asked to participate in this study through a written circular sent home with 700 randomly selected boys and girls from 20 representative rural and urban schools located in the central valley of the country, where the capital of the country, San José, is located. A total of 490 adults offered to collaborate with the investigation, but only 399 of them fulfilled all the inclusion and exclusion criteria.

The final sample consisted of 186 men and 213 women. Written informed consent was obtained from all the participants, and all the procedures that were followed had been approved in accordance with the guidelines of the bioethics committees of the University of Costa Rica and the Costa Rican Institute for Research and Education on Nutrition and Health. Inclusion criteria included being of Costa Rican nationality and being between 20 and 40 years old. The exclusion criteria included a serum creatinine concentration $>133 \mu \mathrm{mol} / \mathrm{L}$ and conditions such as thyroid disease, cancer, pregnancy, and exposure to nitrous oxide. Also excluded were people taking vitamin supplements, anticonvulsants, or antidepressant drugs, as well as women using estrogen therapy.

\section{Study variables}

The study data were collected through validated instruments in faceto-face interviews. The information included age, gender, and the consumption of vitamin supplements or any doctor-prescribed drug. (We excluded from this study all persons who said that they were taking vitamin supplements.) We also registered the presence or absence of cigarette smoking, coffee consumption, and alcoholicbeverage consumption.

Dietary intake was determined by semiquantitative 24-hour recall. Portion size was estimated using a series of photographs of food typically consumed in Costa Rica, along with threedimensional food models. The Food Processor nutrition analysis software, version 6.0 for Windows (Esha Research, Salem, Oregon, United States), was used to perform nutrient calculations from the dietary data (8). A comparison with the United States Dietary Reference Intakes (DRIs) for folate, vitamin $B_{6}$, and vitamin $B_{12}$ was made to evaluate micronutrient intake. Twothirds or less of a DRI was used as the criterion for inadequate dietary intake of a micronutrient (9).

Blood measurements included tHcy, folate, vitamin $\mathrm{B}_{12}$, and creatinine. After 8 to 12 hours of fasting, a venous blood sample was collected from each subject, following National Committee for Clinical Laboratory Standards procedures (10). A plain Vacutainer tube (Becton, Dickinson and Company, Rutherford, New Jersey, United States) was used to obtain serum, and another tube with ethylenediaminetetraacetate (EDTA) was used for DNA extraction. Serum was separated immediately from the blood cells and refrigerated $\left(6{ }^{\circ} \mathrm{C} \pm 2{ }^{\circ} \mathrm{C}\right)$ until further processing. Ascorbic acid (5000 $\mathrm{mg} / \mathrm{L}$ ) was added to the serum aliquot that was reserved for folate analysis in order to preserve the reduced state and stability of the vitamin, as suggested by Henry et al. (11). Samples were subsequently stored at $-20{ }^{\circ} \mathrm{C}$ until analyzed.

\section{Biochemical and genetic analysis}

The serum tHcy level was measured using fluorescence polarization immunoassay, and serum folate and vitamin $B_{12}$ levels were determined with microparticle immunoassays in a fully automated IMx (Abbott Laboratories, Diagnostics Division, Abbott Park, Illinois, United States) (12). Total homocysteine serum levels were categorized as normal $(<10 \mu \mathrm{mol} / \mathrm{L})$, risky (10 to $15 \mu \mathrm{mol} / \mathrm{L})$, or high $(>15 \mu \mathrm{mol} / \mathrm{L})(12$, 13). Creatinine was analyzed by kinetic reactions in a dry chemistry automated VITROS 250 (Johnson \& Johnson, Ortho-Clinical Diagnostics, Rochester, New York, United States) (14). The assays' intra-assay coefficients of variation were $8 \%$ for tHcy, $12 \%$ for folate, $<6 \%$ for vitamin $\mathrm{B}_{12}$ 
TABLE 1. Selected characteristics of the population in study of determinants of serum homocysteine levels, Costa Rica, 2000

\begin{tabular}{|c|c|c|c|}
\hline Variable & $\begin{array}{c}\text { Men } \\
(n=186)\end{array}$ & $\begin{array}{l}\text { Women } \\
(n=213)\end{array}$ & $\begin{array}{c}\text { Total } \\
(n=399)\end{array}$ \\
\hline Age (y) (mean \pm SD) $(95 \% \mathrm{Cl})^{\mathrm{a}, \mathrm{b}}$ & $32.9 \pm 5.5(32.2-33.7)$ & $32.2 \pm 5.7(31.4-32.9)$ & $32.5 \pm 5.6(32.0-33.1)$ \\
\hline Total homocysteine $(\mu \mathrm{mol} / \mathrm{L})($ mean $\pm \mathrm{SD})(95 \% \mathrm{Cl})$ & $10.81 \pm 3.0(10.38-11.25)$ & $8.26 \pm 2.3(7.94-8.57)$ & $9.45 \pm 2.9(9.16-9.74)$ \\
\hline Creatinine $(\mu \mathrm{mol} / \mathrm{L})($ mean $\pm \mathrm{SD})(95 \% \mathrm{Cl})$ & $88.4 \pm 8.8(82.8-96.2)$ & $70.7 \pm 8.8(65.2-87.7)$ & $79.6 \pm 8.8(73.5-86.2)$ \\
\hline \multicolumn{4}{|l|}{ Cigarette smoking } \\
\hline \multicolumn{4}{|l|}{ Coffee consumption } \\
\hline Nondrinker or occasional drinker(\%) ${ }^{c}$ & 24.1 & 23.0 & 23.5 \\
\hline Drinker (\%) & 75.9 & 77.0 & 76.5 \\
\hline \multicolumn{4}{|l|}{ Alcohol consumption } \\
\hline Nondrinker (\%) ${ }^{\mathrm{d}}$ & 47.1 & 74.2 & 61.5 \\
\hline Drinker (\%) & 52.9 & 25.8 & 38.5 \\
\hline
\end{tabular}

a $\mathrm{SD}=$ standard deviation.

b $95 \% \mathrm{Cl}=95 \%$ confidence interval.

${ }^{c}$ Coffee nondrinker or occasional drinker $=$ does not drink coffee or drinks $<1$ cup per month.

d Alcohol nondrinker $=$ drinks $<1$ drink/month.

and $<3 \%$ for creatinine. Genomic DNA was isolated from blood leukocytes using the method of Miller et al. (15). Identification of the $C$ to $T$ substitution at nucleotide 677 of the MTHFR gene was assayed using the method of Frosst et al. (4). Thirty-five cycles at $95^{\circ} \mathrm{C}$ for $60 \mathrm{~s}, 55^{\circ} \mathrm{C}$ for $60 \mathrm{~s}$, and $72{ }^{\circ} \mathrm{C}$ for $90 \mathrm{~s}$ were used to amplify 198-base pair (bp) products. The restriction enzyme Hinf I (Promega Corporation, Madison, Wisconsin, United States) digested the 198-bp fragment into 175-bp and 23-bp fragments, and the analysis was conducted in 3\% agarose (Sigma-Aldrich Corporation, St. Louis, Missouri, United States) electrophoresis. Genetic analyses were performed for only a subset of the population studied (215 of 399) because of the high costs of these techniques. The genetic analyses were done according to the tHcy levels of those persons (102 with tHcy $<9.80 \mu \mathrm{mol} / \mathrm{L}$, and 113 with tHcy $>10.20 \mu \mathrm{mol} / \mathrm{L})$.

\section{Data analysis}

Statistical analysis was performed using SPSS software, version 9.1 for Windows (SPSS Inc., Chicago, Illinois, United States). Continuous variables are summarized using means \pm stan- dard deviation, and categorical variables are presented as frequency distributions. Analysis of variance was performed for continuous variables, and chi-square tests were performed for categorical data. Spearman correlation coefficients were calculated to determine associations between variables. Mann-Whitney nonparametric tests were computed to compare mean levels of serum biochemical indicators among homozygous normal (CC) genotype and heterozygous (CT) genotype, and between TT and non-TT subjects, since the distribution of these variables was skewed. Significance was defined as $P<0.05$. The serum tHcy concentration (the dependent variable) was positively skewed, so the analyses were performed using natural logarithmic transformations. Inverse transformations were done to provide geometric means of tHcy, with $95 \%$ confidence intervals, adjusted by age and gender. Continuous variables were also categorized, using their quartiles as cutoff points. Three multiple linear regression models were developed to determine the best predictors of homocysteine levels. Additionally, a binary logistic model was developed, using serum tHcy concentration $<10 \mu \mathrm{mol} / \mathrm{L}$ or $\geq 10 \mu \mathrm{mol} / \mathrm{L}$ as the dependent variable.

\section{RESULTS}

\section{General characteristics of the population}

The study sample consisted of 399 adults (186 men and 213 women), with a mean age of $32.5 \mathrm{y}( \pm 5.6 \mathrm{y})$ (range 20 to $40 \mathrm{y}$ ) (Table 1). A smoking habit was reported by $18 \%$ of the adults $(27 \%$ of the men vs. $10 \%$ of the women, $P<$ 0.001 ), and $38 \%$ reported consuming alcoholic beverages. In contrast, $77 \%$ of the participants were coffee drinkers.

\section{Biochemical parameters of the population}

Women showed higher mean serum folate levels than men did (27.6 and 25.4 nmol/L, respectively; $P<0.001)$, but men had higher mean serum levels of tHcy and creatinine than did women $(P<0.001)$ (Table 1$)$. No significant differences were found by gender in the mean serum vitamin $B_{12}$ concentrations.

The prevalence of hyperhomocysteinemia ( $>15 \mu \mathrm{mol} / \mathrm{L}$ ) in the total population was $6 \%$ (22 of 399), with the prevalence in men (19 of 186, or $10 \%)$, being much higher than that in women ( 3 of 213 , or $1 \%)(P<0.001)$. In terms of ranges, $31 \%$ of the adults had 
TABLE 2. Distribution (\%) of the population in study of determinants of serum total homocysteine concentrations, according to the total homocysteine concentration categories and cutoff values of serum folate and vitamin $B_{12}$, Costa Rica, 2000

\begin{tabular}{ccccccc}
\hline & \multicolumn{2}{c}{ Folate $(\mathrm{nmol} / \mathrm{L})$} & & \multicolumn{3}{c}{ Vitamin $\mathrm{B}_{12}(\mathrm{pmol} / \mathrm{L})$} \\
\cline { 2 - 3 } Total homocysteine & $\begin{array}{c}<.0 \\
(n=0)\end{array}$ & $\begin{array}{c}\geq 7.0 \\
(n=399)\end{array}$ & & $\begin{array}{c}<165 \\
(n=70)\end{array}$ & $\begin{array}{c}\geq 165 \\
(n=329)\end{array}$ & $P$ value $^{\mathrm{a}}$ \\
\hline$<10 \mu \mathrm{mol} / \mathrm{L}$ & 0.0 & 63.9 & & 42.8 & 69.9 & 0.001 \\
$10-15 \mu \mathrm{mol} / \mathrm{L}$ & 0.0 & 30.6 & & 48.6 & 27.1 & 0.001 \\
$>15 \mu \mathrm{mol} / \mathrm{L}$ & 0.0 & 5.5 & & 8.6 & 3.0 & 0.066 \\
Total & 0.0 & 100.0 & & 100.0 & 100.0 & \\
\hline
\end{tabular}

a $P$ value according to chi-square test.

tHcy concentrations ranging between 10 and $15 \mu \mathrm{mol} / \mathrm{L}(50 \%$ of the men vs. $14 \%$ of the women, $P<0.001)$, and $64 \%$ showed normal tHcy levels $(<10$ $\mu \mathrm{mol} / \mathrm{L})(85 \%$ of the women vs. $40 \%$ of the men, $P<0.001)$. The prevalence of hyperhomocysteinemia was $5 \%$ among those 20-29 years old, and 6\% among those 30-40 years old.

None of the adults in this study presented low serum concentrations of folate $(<7.0 \mathrm{nmol} / \mathrm{L})$ (Table 2$)$. In contrast, 70 of the 399 adults (18\%) showed deficient levels of serum vitamin $\mathrm{B}_{12}$ $(<165 \mathrm{pmol} / \mathrm{L}), 34$ of $70(49 \%)$ of the adults with low serum levels of vitamin $B_{12}$ showed risky serum levels of tHcy $(10-15 \mu \mathrm{mol} / \mathrm{L}, P<0.001)$, and 6 of $70(9 \%)$ had hyperhomocysteinemia. Serum creatinine showed a strong direct correlation with tHcy $(r=0.472)$, while folate and vitamin $B_{12}$ presented an inverse relationship with it $(r=$ -0.267 and $r=-0.309$, respectively).

\section{Methylenetetrahydrofolate reductase genotypes}

The proportion of persons in the study with the homozygous normal (CC) genotype for MTHFR was 32\% (69 of 215); heterozygous (CT) genotype, 39\% (84 of 215); and homozygous mutant (TT) genotype, 29\% (62 of 215) (Table 3). The frequencies of the alleles 677C and 677T were $52 \%$ (111 of 215) and $48 \%$ (104 of 215), respectively. The mean serum tHcy concentration in the adults with the TT genotype was higher $(12.30 \mu \mathrm{mol} / \mathrm{L})$ than in the subjects with non-TT genotypes $(\mathrm{CC}+\mathrm{CT})(9.89$ $\mu \mathrm{mol} / \mathrm{L})(P<0.001)$. Lower serum levels of folate were observed in homo- zygous mutant adults than in non-TT subjects (23.3 nmol/L vs. $26.5 \mathrm{nmol} / \mathrm{L}$, respectively, $P<0.001)$. A higher proportion of adults with the non-TT genotypes than those with the TT genotype for MTHFR showed tHcy levels $<10$ $\mu \mathrm{mol} / \mathrm{L}(52 \%$ and $27 \%$, respectively, $P=0.002$ ) (data not shown). Of the 62 TT carriers, 12 of them (19\%) presented hyperhomocysteinemia, versus 5 of the 153 non-TT individuals $(3 \%)(P<0.001)$. No significant differences were found in the mean serum concentrations of folate, vitamin $B_{12}$, and $\mathrm{tHcy}$ between the subjects with CC genotype and those with the CT genotype.

\section{Dietary vitamin intake}

In terms of dietary vitamin intake, $77 \%$ of the adults reported an adequate intake of folate, and $82 \%$ for vitamin $\mathrm{B}_{6}$. Fewer than $0.5 \%$ of the subjects consumed less than one-third of the DRIs for vitamin $\mathrm{B}_{6}$ and folate. In contrast, $46 \%$ of women and $32 \%$ of men did not meet two-thirds of the DRI for vitamin $\mathrm{B}_{12}$. In addition, $12 \%$ of the adults did not even meet onethird of the DRI for this vitamin.

\section{Geometric means of total homocysteine concentrations}

The geometric mean of $\mathrm{tHcy}$ concentrations was $27 \%$ higher in men (10.43

TABLE 3. Levels of some of the biochemical parameters of a subset ( 215 persons) of the population in study of determinants of serum homocysteine concentrations, according to their methylenetetrahydrofolate reductase (MTHFR) genotype, Costa Rica, 2000

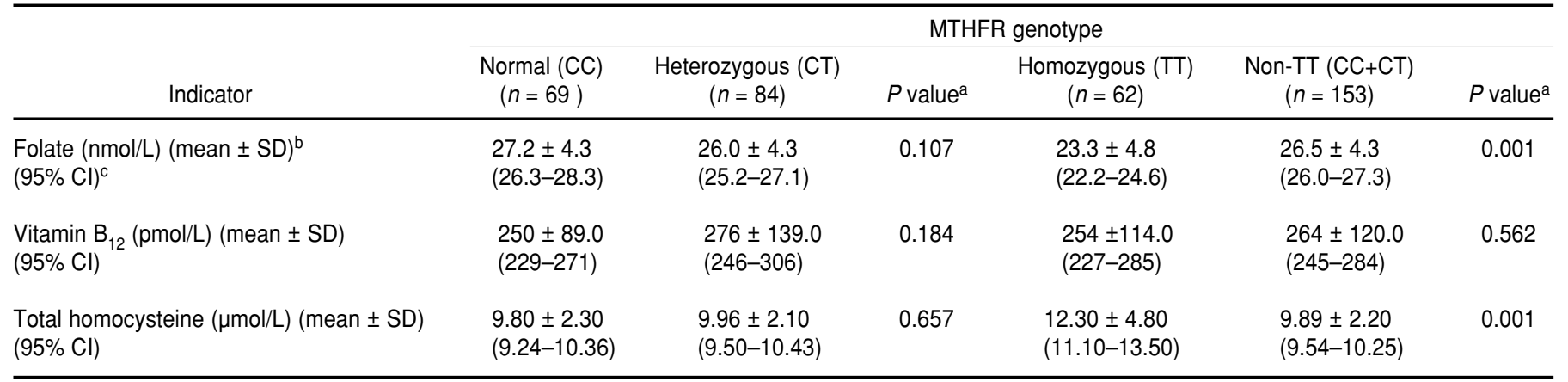

\footnotetext{
a $P$ value according to Mann-Whitney test

${ }^{b} \mathrm{SD}=$ standard deviation.

c $95 \% \mathrm{Cl}=95 \%$ confidence interval.
} 
$\mu \mathrm{mol} / \mathrm{L})$ than in women $(8.21 \mu \mathrm{mol} / \mathrm{L})$ $(P<0.001)$, and it was $8 \%$ higher in the subjects with serum creatinine levels $\geq 88.4 \mu \mathrm{mol} / \mathrm{L}(P=0.011)$ (Table 4$)$. The tHcy concentrations were similar in the two studied age groups (20-29 y and 30-40 y). After multivariate adjustment for age and gender, the geometric mean tHcy concentration was $17 \%$ higher in the lowest quartile of serum vitamin $B_{12}$ than in the highest quartile $(P<0.001)$. Similarly, a $16 \%$ difference was found between the lowest and the highest quartiles for serum folate $(P<0.001)$. The geometric mean tHcy concentration in coffee drinkers was 5\% higher than in nondrinkers $(9.64 \mu \mathrm{mol} / \mathrm{L}$ versus 9.14 $\mu \mathrm{mol} / \mathrm{L} ; P=0.047$ ).

No significant differences were found in the tHcy concentrations between the smokers and nonsmokers, and the alcohol drinkers and nondrinkers, or among the different quartiles of dietary vitamin intake (data not shown).

\section{Linear and logistic regression models}

According to the linear regression model (Table 5), the main predictors of the serum levels of tHcy were the serum levels of vitamin $B_{12}$ and folate, gender, and the presence of the TT mutation in the MTHFR gene. This model explained $34 \%$ of the variance of the tHcy concentrations in the population.

Excluding the nonsignificant variables (age, dietary vitamin intake, coffee drinking, and smoking), a second model (Table 6) established that the tHcy levels were $14.5 \%$ higher in men than in women, and $13.6 \%$ higher in subjects with the TT genotype than in the non-TT adults. Additionally, this model indicated that a $1 \%$ reduction in the serum levels of vitamin $B_{12}$ and folate increased the tHcy levels $20.1 \%$ and $35.4 \%$, respectively, keeping the rest of the variables constant.

The inclusion of the natural logarithm of folate, vitamin $B_{6}$, and vita$\min B_{12}$ intakes in a third linear regression model (not shown) explained an additional 3\% of the variance of tHcy compared to the second model $\left(R^{2}=\right.$ 0.307 for the third model vs. $R^{2}=0.282$ for the second model).

TABLE 4. Geometric mean of total serum homocysteine concentration, with $95 \%$ confidence interval $(95 \% \mathrm{Cl})$, for suspected and established determinants of total homocysteine concentrations, after adjustment for age and sex, Costa Rica, 2000

\begin{tabular}{|c|c|c|c|}
\hline \multirow[b]{2}{*}{ Variable } & \multicolumn{2}{|c|}{ Total homocysteine $(\mu \mathrm{mol} / \mathrm{L})$} & \multirow[b]{2}{*}{$P^{a}$} \\
\hline & Mean & $95 \% \mathrm{Cl}$ & \\
\hline \multicolumn{4}{|l|}{ Gender } \\
\hline Men $(n=186)$ & 10.43 & $10.06-10.82$ & \\
\hline Women $(n=213)$ & 8.21 & $7.94-8.48$ & 0.001 \\
\hline \multicolumn{4}{|l|}{ Age (years): } \\
\hline 20 to $29(n=163)$ & 9.18 & $8.85-9.53$ & \\
\hline 30 to $40(n=236)$ & 9.33 & $9.03-9.63$ & 0.490 \\
\hline \multicolumn{4}{|l|}{ Vitamin $B_{12}(p m o l / L):$} \\
\hline$<181(n=95)$ & 10.17 & $9.70-10.66$ & \\
\hline $181-240(n=101)$ & 9.48 & $9.05-9.92$ & 0.029 \\
\hline $241-317(n=101)$ & 8.75 & $8.36-9.16$ & 0.001 \\
\hline$\geq 318(n=102)$ & 8.70 & $8.31-9.11$ & 0.001 \\
\hline \multicolumn{4}{|l|}{ Folate (nmol/L): } \\
\hline$<24.2(n=97)$ & 10.48 & $10.00-10.97$ & \\
\hline $24.2-27.0(n=94)$ & 9.04 & $8.62-9.49$ & 0.001 \\
\hline $27.1-29.7(n=105)$ & 8.58 & $8.19-8.97$ & 0.001 \\
\hline$\geq 29.8(n=103)$ & 9.02 & $8.61-9.45$ & 0.001 \\
\hline \multicolumn{4}{|l|}{ Creatinine $(\mu \mathrm{mol} / \mathrm{L})$ : } \\
\hline$<88.4(n=302)$ & 9.09 & $8.83-9.36$ & \\
\hline$\geq 88.4(n=97)$ & 9.82 & $9.32-10.34$ & 0.011 \\
\hline \multicolumn{4}{|l|}{ Coffee consumption: } \\
\hline Nondrinkers $(n=94)$ & 9.14 & $8.89-9.41$ & \\
\hline Drinkers $(n=305)$ & 9.64 & $9.19-10.13$ & 0.047 \\
\hline \multicolumn{4}{|l|}{ Cigarette consumption: } \\
\hline Nonsmokers $(n=328)$ & 9.18 & $8.69-9.70$ & \\
\hline Smokers $(n=71)$ & 9.27 & $9.01-9.54$ & 0.751 \\
\hline
\end{tabular}

The binary logistic regression model (Table 7) established that the risk of having hyperhomocysteinemia was 3.13 times as high in the TT subjects as in the non-TT ones. The risk of having high tHcy decreases $3 \%$ for each 10pmol increase in serum vitamin $B_{12}$. Serum folate levels and gender were not significant predictors of high tHcy concentrations in the population.

\section{DISCUSSION}

The prevalence of hyperhomocysteinemia (that is, $>15 \mu \mathrm{mol} / \mathrm{L}$ ) in the Costa Rican population studied (6\%) is similar to the one estimated for the general population of the United States (5\%) (16). In young AsianIndian residents in the United State this prevalence is $26 \%$ for men and women (17), and the prevalence is $77 \%$ for men and women in the country of India (18). There are few studies from around the world that have been done on young healthy adults (20-40 y) and their serum tHcy concentrations, thus making comparisons difficult. Nevertheless, the geometric means of tHcy concentrations for the Costa Ricans in our study were slightly higher than the ones reported in the few works done on subjects less than 40 years old $(19,20)$.

Contrary to other studies $(19,21)$, in our study in Costa Rica no relationship was found between age and tHcy concentrations. That was probably because the selected population was relatively young (20 to $40 \mathrm{y}$ ). Increases of $1 \mu \mathrm{mol} / \mathrm{L}$ in the tHcy concentration 
TABLE 5. Linear regression analysis (Model 1) using the natural logarithm of the serum total homocysteine concentrations as the dependent variable in study of determinants of serum homocysteine concentrations, Costa Rica, 2000a

\begin{tabular}{|c|c|c|}
\hline Independent variable & $\beta^{b}$ & $P$ \\
\hline Gender ${ }^{c}$ & 0.205 & 0.002 \\
\hline Age & 0.002 & 0.969 \\
\hline Lnd $^{\text {d serum vitamin }} B_{12}$ & -0.309 & 0.001 \\
\hline Ln serum folate & -0.267 & 0.001 \\
\hline Ln intake $B_{6}$ & 0.110 & 0.144 \\
\hline Ln intake $B_{12}$ & -0.099 & 0.158 \\
\hline Ln intake folate & 0.005 & 0.928 \\
\hline Coffee drinkere & -0.084 & 0.276 \\
\hline Smoker ${ }^{f}$ & 0.048 & 0.441 \\
\hline $\begin{array}{l}\text { TT mutation }{ }^{9} \text { in } \\
\text { gene of MTHFR }\end{array}$ & 0.222 & 0.001 \\
\hline
\end{tabular}

a The variables included in this model explained $34 \%$ of the variance in the total homocysteine levels in the studied population.

b $\beta=$ slope of the line for the population studied

${ }^{c}$ For gender, men $=1$, women $=0$.

${ }^{d} \mathrm{Ln}=$ natural logarithm.

${ }^{\mathrm{e}}$ Coffee drinker $=1$, nondrinker $=0$

${ }^{\dagger}$ Cigarette smoker $=1$, nonsmoker $=0$.

$\mathrm{g} \mathrm{TT}=1$, non- $\mathrm{TT}=0$

${ }^{\mathrm{h}}$ MTHFR = methylenetetrahydrofolate reductase enzyme.

have been observed for each decade between 40 and 70 years (22). Furthermore, it has been suggested that high tHcy concentrations in older subjects could be related to an age-associated decrease in the activity of the enzymes involved in homocysteine metabolism or in renal function (23).

The higher serum tHcy concentrations in men than in women that we found in Costa Rica are consistent with the results of other research, suggesting that sex hormones could play an important role in tHcy metabolism (23). High levels of tHcy have been reported in menopausal women who are not undergoing estrogen replacement therapy, while those treated with these hormones have lower serum tHcy concentrations (24). In addition, other research (25) has found an association between creatinine levels and high tHcy concentrations in men, but not in women. This has been explained in terms of body composition, since men have higher muscle mass than women do.

Several lifestyle variables have been associated with hyperhomocysteinemia. In the cohort work with the de-

TABLE 6. Linear regression analysis (Model 2) using the natural logarithm of the serum total homocysteine concentrations as the dependent variable in study of determinants of serum homocysteine concentrations, Costa Rica, 2000a

\begin{tabular}{|c|c|c|}
\hline Independent variable & $\beta^{b}$ & $P$ \\
\hline $\mathrm{Ln}^{\mathrm{c}}$ serum vitamin $\mathrm{B}_{12}$ & -0.201 & 0.001 \\
\hline Ln serum folate & -0.354 & 0.001 \\
\hline Gender $^{d}$ & 0.145 & 0.001 \\
\hline TT mutation in gene of MTHFR $^{\dagger}$ & 0.136 & 0.001 \\
\hline
\end{tabular}

a The variables included in this model explained $28 \%$ of the variance in the total homocysteine levels in the studied population.

${ }^{b} \beta=$ slope of the line for the population studied.

$c \mathrm{Ln}=$ natural logarithm of the serum concentrations of vitamins.

${ }^{\mathrm{d}}$ Men $=1$, women $=0$.

e TT $=1$, non- $\mathrm{TT}=0$

${ }^{f}$ MTHFR = methylenetetrahydrofolate reductase enzyme

TABLE 7. Binary logistic regression model using the serum levels of tHcy $<10 \mu \mathrm{mol} / \mathrm{L}$ or $\geq 10 \mu \mathrm{mol} / \mathrm{L}$ as the dependent variable in study of determinants of serum homocysteine concentrations, Costa Rica, 2000

\begin{tabular}{|c|c|c|}
\hline Independent variable & $\mathrm{OR}^{\mathrm{a}}$ & $P$ \\
\hline Gender ${ }^{b}$ & 1.6356 & 0.1445 \\
\hline Age & 0.9926 & 0.7730 \\
\hline TT mutation ${ }^{c}$ in MTHFR ${ }^{d}$ gene & 3.1287 & 0.0017 \\
\hline Serum vitamin $\mathrm{B}_{12}(\mathrm{pmol} / \mathrm{L})$ & 0.9971 & 0.0048 \\
\hline Serum folate $(\mathrm{nmol} / \mathrm{L})$ & 0.9979 & 0.9779 \\
\hline
\end{tabular}

scendants of the Framingham Study (20) and of the Hordaland Study (21), a positive association was observed between smoking and the serum tHcy concentrations. Likewise, several studies have reported a positive association between alcohol consumption and serum tHcy concentrations (2). In our Costa Rica study the serum tHcy concentrations were found to be associated with coffee consumption, in accord with previous reports $(20,21,26)$. No significant relationship was observed between tHcy concentrations and other lifestyle variables.

In our study the intake of folate and of vitamin $\mathrm{B}_{6}$ both showed weak positive correlations $(r<0.2)$ with serum tHcy concentrations; however, the associations disappeared after multivariate adjustment for age and gender. In contrast, Saw et al. (26) and de Bree et al. (2) have reported a strong inverse association between folate ingestion and tHcy concentrations. Although 24hour recall has demonstrated a good correlation with other dietary assessment methods in nutritional epidemiology (20), in our study it was unable to adequately assess the daily intake of folate, vitamin $\mathrm{B}_{6}$, and vitamin $\mathrm{B}_{12}$. Nevertheless, the intake data for these three vitamins together explained around $3 \%$ of the variance in the serum tHcy levels, according to our third linear regression model.

In both our work in Costa Rica and in other epidemiologic studies $(20,22$, 23) an inverse correlation between the serum concentrations of some vitamins (especially folate and $\mathrm{B}_{12}$ ) and tHcy was found. Data from the Framingham Study (23) indicated that $67 \%$ of the subjects with suboptimal levels 
of one or more of these vitamins presented high tHcy levels. Folate, in the form of 5-methyltetrahydrofolate, has been considered the most important dietetic determinant of serum Hcy concentrations (2). Multiple intervention and fortification assays (27) have established that folic acid is the most effective vitamin of the B complex for lowering high levels of homocysteine in apparently healthy subjects, using doses as small as 100-400 $\mu \mathrm{g}$ / daily.

A food fortification program was started by the Ministry of Health of Costa Rica in 1997. In 1996, Kim et al. (28) carried out a study in which they found that $98 \%$ of the subjects had folate intakes that were less than the recommended $400 \mathrm{ug} /$ day. In women, the mean plasma folate level was 7.9 $( \pm 2.2) \mathrm{nmol} / \mathrm{L}$, and $36 \%$ of them had concentrations of less than $6.8 \mathrm{nmol} / \mathrm{L}$, a clear indicator of folate deficiency. In 1997 the Ministry of Health made the enrichment of wheat flour with folic acid obligatory (29). This was extended to corn flour in 1999, milk in 2001, and rice in 2002. Although the purpose of this supplementation was to reduce the number of children born with neural tube defects (anencephaly, spina bifida), this fortification program probably had an important collateral effect on CVD. Since all the adults in our study were characterized by serum fo- late sufficiency, measuring their serum folate levels was not as useful in predicting elevated tHcy concentrations as would be true in countries that do not fortify food with folic acid (21-23).

The presence of the TT mutation in the gene that codes for the MTHFR enzyme had the highest predictive value for high levels of tHcy in our Costa Rica study population. The prevalence of this genotype was higher $(29 \%)$ than the level reported in various other countries $(2.5 \%-16 \%)(3,18,26,30)$. Only Caucasians (36\%) and Asians $(40 \%)$ have higher prevalences of this homozygous mutation than did the persons in our Costa Rica study (31). It's easy to explain the high prevalence of the TT mutation in the MTHFR gene that we found, given that present-day Costa Ricans represent an ancestral gene combination of some 10-15\% African, 30\% Amerindian, and 50-60\% Caucasian origin. The frequency of both alleles ( $\mathrm{C}$ and $\mathrm{T}$ ) is practically the same, so the probability that this point mutation in nucleotide 677 is inherited in a homozygous way is high.

Even though this TT mutation is considered a nonmodifiable factor for hyperhomocysteinemia, it's important to diagnose the individuals with the TT genotype in the population in order to identify the people who could most benefit from nutrition interventions.
The vitamin $B_{12}$ serum level in the population in Costa Rica was the second most important predictor of high $\mathrm{tHcy}$ levels, so it may be appropriate to consider the supplementation of food with vitamin $\mathrm{B}_{12}$. In randomized intervention trials assessing the effects of cobalamin in lowering serum tHcy concentrations, reductions of around 7\% in the levels of this amino acid have been seen (32). Recent research is giving greater importance to cobalamin levels as a determinant of tHcy concentrations. These studies suggest that enhancing vitamin $B_{12}$ status may significantly decrease tHcy levels in people, especially in those individuals with C677T MTHFR polymorphism $(33,34)$.

Future research should also evaluate the intake and serum levels of other vitamins that are involved in the metabolic cycle of homocysteine, such as $\mathrm{B}_{6}$ and $\mathrm{B}_{2}$. Any effort along these lines is justified, given that for each $1-\mu \mathrm{mol} / \mathrm{L}$ decrease in serum $\mathrm{tHcy}$, cardiovascular risk goes down by $10 \%$ (2).

Acknowledgments. This work was supported by grants from three sources at the University of Costa Rica: (1) Office of Postgraduate Studies, (2) Office of Vice-president for Research (Project 807-A2-308), and (3) Fundación de la Universidad de Costa Rica para la Investigación (Project 217).

\section{REFERENCES}

1. Molgaard J, Malinow MR, Lassvik C, Holm AC, Upson B, Olsson AG. Hyperhomocyst(e)inaemia: an independent risk factor for intermittent claudication. J Intern Med. 1992; 231:272-9.

2. de Bree A, Verschuren WM, Blom HJ, Kromhout D. Association between B vitamin intake and plasma homocysteine concentration in the general Dutch population aged 2065 y. Am J Clin Nutr. 2001;73(6):1027-33.

3. Jacques PF, Bostom AG, Williams RR, Ellison $\mathrm{RC}$, Eckfeldt JH, Rosenberg IH, et al. Relation between folate status, a common mutation in methylenetetrahydrofolate reductase, and plasma homocysteine concentrations. Circulation. 1996;93:7-9.

4. Frosst P, Blom HJ, Milos R, Goyette P, Sheppard CA, Mathews RG, et al. A candidate genetic risk factor for vascular disease: a common mutation in methylenetetrahydrofolate reductase. Nature Genetics. 1995;10:111-3.
5. Boushey CJ, Beresford SAAA, Omenn GS, Motulsky AG. A quantitative assessment of plasma homocysteine as a risk factor for vascular disease. Probable benefits of increasing folic acid intakes. JAMA. 1995;274: 1049-57.

6. Costa Rica, Ministerio de Salud, Departamento de Estadística. Mortalidad por enfermedades del aparato circulatorio. San José: Ministerio de Salud; 1996.

7. Campos H, Mata L, Siles X, Vives M, Ordovas JM, Schaefer EJ. Prevalence of cardiovascular risk factors in rural and urban Costa Rica. Circulation. 1992;85:648-58.

8. ESHA Research. The Food Processor for Windows: nutrition and fitness software, version 6.0 [computer program]. Salem: ESHA Research; 1995.

9. Yates AA, Schlicker SA, Suitor CW. Dietary Reference Intakes: the new basis for recommendations for calcium and related nutrients,
B vitamins, and choline. J Am Diet Assoc. 1998;98:699-706.

10. National Committee for Clinical Laboratory Standards. Procedures for the collection of diagnostic blood specimens by venipuncture; approved standard. 4th ed. Wayne: NCCLS; 1991.

11. Henry RJ, Cannon DC, Winkelman JW. Clinical chemistry: principles and technics. 2nd ed. New York: Harper \& Row Publishers; 1974.

12. Abbott Laboratories, Diagnostics Division. IMx system: homocysteine, vitamin $B_{12}$ and folate. Abbott Park: Abbott Laboratories; 1998.

13. Jacobsen DW. Homocysteine and vitamins in cardiovascular disease. Clin Chem. 1998;44: 8(B); $1833-43$

14. Johnson \& Johnson. Dry slide technology. Rochester: Johnson \& Johnson; 1996.

15. Miller SA, Dykes DD, Polesky HF. A simple salting out for extracting DNA from human 
nucleated cells. Nucleic Acids Res. 1988;16: 1215-20.

16. Hankey GJ, Eikelboom JW. Homocysteine and vascular disease. Lancet. 1999;354:407-13.

17. Carmel R, Mallidi PV, Vinarskiy S, Brar S, Frouhar S. Hyperhomocysteinemia and cobalamin deficiency in young Asian Indians in the USA. Am J Hematol. 2002;70(2):107-14.

18. Refsum H, Yajnik CS, Gadkari M, Schneede J, Vollset SE, Orning L, et al. Hyperhomocysteinemia and elevated methylmalonic acid indicate a high prevalence of cobalamin deficiency in Asian Indians. Am J Clin Nutr. 2001; 74(2):233-41.

19. Jacques PF, Rosenberg IH, Rogers G, Selhub J, Bowman BA, Gunter EW, et al. Serum total homocysteine concentrations in adolescent and adult Americans: results from the third National Health and Nutrition Examination Survey. Am J Clin Nutr. 1999;69:48-9.

20. Jacques PF, Bostom AG, Wilson PW, Rich S, Rosenberg IH, Selhub J. Determinants of plasma total homocysteine concentration in the Framingham Offspring cohort. Am J Clin Nutr. 2001;73:613-21.

21. Vollset SE, Refsum H, Tverdal A, Nygard O, Nordrehaug JE, Tell GS, et al. Plasma total homocysteine and cardiovascular and noncardiovascular mortality: the Hordaland Homocysteine Study. Am J Clin Nutr. 2001;74:130-6.

22. Selhub J, Jacques PF, Rosenberg IH, Rogers G, Bowman BA, Gunter EW, et al. Serum total homocysteine concentrations in the Third National Health and Nutrition Examination Sur- vey (1991-1994): population reference ranges and contribution of vitamin status to high serum concentrations. Ann Intern Med. 1999; 131:331-9.

23. Selhub J, Jacques PF, Wilson PW, Rush P, Rosenberg IH. Vitamin status and intake as primary determinants of homocysteinemia in an elderly population. JAMA. 1993;270: 2693-8.

24. Van der Mooren MJ, Wouters MG, Blom HJ, Schellekens LA, Eskes TK, Rolland R. Hormone replacement therapy may reduce high serum homocysteine in postmenopausal women. Eur J Clin Invest. 1994;24:733-6.

25. Bostom AG, Culleton BF. Hyperhomocysteinemia in chronic renal disease. J Am Soc Nephrol. 1999;10:891-900.

26. Saw SM, Yuan JM, Ong CN, Arakawa K, Lee $\mathrm{HP}$, Coetzee GA, et al. Genetic, dietary, and other lifestyle determinants of plasma homocysteine concentrations in middle-aged and older Chinese men and women in Singapore. Am J Clin Nutr. 2001;73:232-9.

27. Brouwer IA. Low-dose folic acid supplementation decreases plasma homocysteine concentrations: a randomized trial. Am J Clin Nutr. 1999;69:99-104.

28. Kim MK, Ordovas JM, Selhub J, Campos H. B vitamins and plasma homocysteine concentrations in an urban and rural area of Costa Rica. J Am Coll Nutr. 2003;22(3):224-31.

29. Instituto Costarricense de Investigación y Enseñanza en Nutrición y Salud, Centro de Registro de Enfermedades Congénitas. Prevalen- cia de enfermedades congénitas por provincia y cantones: Costa Rica, 1987-2000. Tres Ríos: INCIENSA; 2002.

30. Schneider JA, Rees DC, Liu YT, Clegg JB. Worldwide distribution of a common methylenetetrahydrofolate reductase mutation. Am J Hum Genet. 1998;62:1258-60.

31. Franco RF, Araujo AG, Guerreiro JF, Elion J, Zago MA. Analysis of the $677 \mathrm{C} \rightarrow \mathrm{T}$ mutation of the methylenetetrahydrofolate reductase gene in different ethnic groups. Thromb Haemost. 1998;79:119-21.

32. Homocysteine Lowering Trialists' Collaboration. Lowering blood homocysteine with folic acid based supplements: meta-analysis of randomized trials. BMJ. 1998;316:894-8.

33. Bailey LB, Duhaney RL, Maneval DR, Kauwell GP, Quinlivan EP, Davis SR, et al. Vitamin $B_{12}$ status is inversely associated with plasma homocysteine in young women with C677T and/or A1298C methylenetetrahydrofolate reductase polymorphisms. J Nutr. 2002; 132(7):1872-8.

34. Herrmann W, Obeid R, Schorr H, Zarzour W, Geisel J. Homocysteine, methylenetetrahydrofolate reductase $\mathrm{C677T}$ polymorphism and the B-vitamins: a facet of nature-nurture interplay. Clin Chem Lab Med. 2003;41(4):547-53.

Manuscript received 2 August 2004. Revised version accepted for publication 7 February 2005.

RESUMEN Objetivo. La elevación de las concentraciones séricas de homocisteína total (tHci) se considera un factor que influye de forma independiente en el riesgo de sufrir trastornos cardiovasculares. El objetivo del presente estudio ha sido aportar los primeros

Factores genéticos y alimentarios y otros aspectos del estilo de vida que determinan las concentraciones séricas de homocisteína en adultos jóvenes en Costa Rica

Palabras clave datos que jamás se han reunido acerca de la prevalencia de hiperhomocisteinemia y sus factores determinantes en una población costarricense.

Métodos. Se llevó a cabo un estudio transversal a fin de determinar las concentraciones séricas de $\mathrm{tHci}$, vitamina B12, folato y creatinina, así como la presencia del genotipo TT respecto de la enzima reductasa del metilenotetrahidrofolato (RMTHF). También se examinaron la ingestión de vitaminas y otros factores de riesgo relacionados con el estilo de vida. Participaron en el estudio, que se realizó en 2000, 399 adultos costarricenses de 20 a 40 años de edad del valle central del país (donde está San José, la capital). Se realizaron análisis de la varianza en el caso de las variables continuas, y se aplicó la prueba de ji al cuadrado en el caso de datos categóricos. Se efectuaron pruebas de correlación de Spearman para determinar la asociación entre distintas variables. Se llevaron a cabo tres análisis de regresión lineal y un modelo logístico para datos binarios a fin de determinar qué factores servían para pronosticar las concentraciones de homocisteína en la población estudiada.

Resultados. La prevalencia general de hiperhomocisteinemia ( $>15 \mu \mathrm{mol} / \mathrm{L})$ en la población fue de $6 \%$; en $31 \%$ de la muestra se detectaron concentraciones entre 10 y 15 $\mu \mathrm{mol} / \mathrm{L}$; en $29 \%$ se halló el genotipo TT respecto de la enzima RMTHF; $18 \%$ tuvieron deficiencia de vitamina B12 $(<165 \mathrm{pmol} / \mathrm{L})$, y nadie tuvo bajas concentraciones séricas de folato $(<7,0 \mathrm{nmol} / \mathrm{L})$. No se hallaron asociaciones significativas entre tHci en el suero, edad, hábitos tabáquicos, el consumo de alcohol o la ingestión de vitaminas. Conclusiones. Solamente las concentraciones séricas de vitamina B12 y el genotipo TT respecto de la enzima RMTHF mostraron tener valor pronóstico con respecto a las concentraciones séricas de tHci en la población costarricense aquí estudiada.

Enfermedades cardiovasculares, homocisteína, estilo de vida, factores de riesgo, Costa Rica. 